\title{
Analisis Implementasi Bimbingan dan Konseling Terhadap Tiga Sekolah di Jawa Tengah dengan Status Pembelajaran Daring
}

\author{
Hilda Sifalia Nurlatifah*, Silvia Rahmawati, Himmatur Rofi'ah, Bunga Ihda Norra \\ Universitas Islam Negeri Walisongo Semarang, Jl. Walisongo No.3-5 Semarang, Jawa Tengah, \\ Indonesia \\ *Penulis korespondensi, Surel: hildasifalia55@gmail.com
}

Paper received: 2-11-2021; revised: 17-11-2021; accepted: 23-11-2021

\begin{abstract}
Abstrak
Adanya perubahan sistem belajar dari pembelajaran luring ke pembelajaran daring akibat pandemi, memaksa semua aktivitas yang berhubungan dengan pendidikan dilaksanakan secara online, termasuk dalam memberikan pelayanan bimbingan dan konseling kepada siswa. Terkait hal itu, penelitian ini dirancang untuk memahami dan memaparkan peran guru BK dalam layanan bimbingan konseling pada siswa di masa pandemi, serta tanggapan siswa mengenai pelayanan yang diberikan. Penelitian ini menggunakan metode mixed method design sequence. Metode ini dipilih dengan tujuan agar hasil yang didapatkan lebih akurat dan maksimal. Pendekatan kualitatif dirancang untuk mengetahui cara BK bekerja di sekolah. Sedangkan pendekatan kuantitatif digunakan untuk mengetahui berapa banyak siswa yang memanfaatkan layanan konseling dan ada tidaknya layanan bimbingan dan konseling yang ditawarkan oleh guru BK di masa pandemi. Teknik pengumpulan data menggunakan metode wawancara mendalam, studi deskriptif, observasi, dokumentasi, dan menggunakan observasi tes tulis dengan pengisian lewat google form. Dari wawancara dan kuisioner dari tiga guru dan sembilan siswa di tiga sekolah berbeda, didapatkan hasil bahwa layanan bimbingan dan konseling tetap dilakukan di masa pandemi dengan memanfaatkan media digital seperti WhatsApp dan Google Classroom. Namun, jika dirasa kurang memuaskan, maka akan dilanjutkan dengan melakukan kunjungan ke rumah siswa yang berkaitan. Sedangkan untuk hasil tanggapan siswa mengenai layanan bimbingan dan konseling, beberapa siswa ternyata tidak mengetahui informasi layanan dan tidak pernah melakukan Bimbingan Konseling, sehingga perlu adanya penyebaran informasi secara merata kepada siswa. Dan beberapa yang lain mengetahui layanan tersebut, tetapi malu untuk melakukan bimbingan dan konseling, karena berpikir hanya siswa yang bermasalah yang melakukan bimbingan dan konseling.
\end{abstract}

Kata kunci: bimbingan; konseling, peran; layanan; pandemi

\section{Pendahuluan}

Maret 2020 sampai dengan hari ini pandemi COVID-19 yang melanda negeri ini belum juga berakhir. Masyarakat semakin merasa ketakutan karena korban masih terus berjatuhan. Jawa tengah merupakan daerah di mana peneliti berada yang memiliki persentase kasus COVID-19 yang cukup tinggi. Jumlah orang yang terinfeksi virus COVID-19 serta meninggal akibat kasus COVID-19 terus bertambah setiap harinya (Purwaningsih, 2021).

COVID-19 merupakan jenis virus yang baru sehingga banyak pihak yang tidak tahu dan tidak mengerti cara penanggulangan virus tersebut. COVID-19 terus menerus menular ke seluruh belahan dunia. Seiring adanya wabah virus COVID-19 atau virus Corona ke berbagai negara, pemerintah Republik Indonesia menerapkan protokol kesehatan. Protokol tersebut dilaksanakan di seluruh Indonesia oleh pemerintah dengan dipandu secara terpusat oleh Kementrian Kesehatan RI . 
Berbagai upaya untuk memutus rantai penyebaran virus COVID-19 telah dilakukan oleh pemerintah. Membatasi kegiatan warga masyarakat di luar rumah merupakan salah satu kebijakan pemerintah. Penerapan aturan Pembatasan Sosial Berskala Besar (PSBB) berupa larangan berkumpul, sudah ditegaskan pemerintah dari awal pandemi mewabah (Tambusai, 2020). Lembaga pendidikan yaitu sekolah tidak luput dari kebijakan tersebut. Surat edaran Mendikbud No. 36962/MPK.A/HK/2020 tentang Pembelajaran secara Daring dan Bekerja dari Rumah dalam Rangka Pencegahan Penyebaran Coronavirus Disease (COVID-19) tertanggal 17 Maret 2020 merupakan landasan sekolah dalam melaksanakan pembelajaran dari rumah. Terbitnya surat edaran nomor 4 tahun 2020 yang dikeluarkan tanggal 24 Maret 2020 untuk memperkuat pembelajaran secara daring. Surat edaran tersebut tentang Pelaksanaan Kebijakan Pendidikan dalam Masa Darurat Penyebaran Coronavirus Disease. (Tambusai, 2020).

Terhitung mulai dari pertengahan bulan Maret 2020 sampai sekarang peserta didik melaksanakan Pembelajaran Jarak Jauh (PJJ). Metode yang digunakan dalam Pembelajaran Jarak Jauh (PJJ) yaitu daring atau online, peserta didik diharuskan dapat mengontrol sikapnya dalam belajar, menyelesaikan tugas melalui daring atau online dan harus mengoptimalkan gadget sebagai sumber belajar, dalam hal ini peserta didik harus memiliki sikap tanggung jawab mandiri dalam belajar. Namun, menurut surat kabar Kompas (2020) disampaikan terdapat beberapa hambatan pembelajaran daring atau online yang dialami oleh peserta didik. Salah satunya yaitu mengalami kebosanan tinggal di rumah. Dalam hal ini peran Bimbingan Konseling sangatlah penting dalam membantu mengatasi permasalahan peserta didik selama pembelajaran daring atau online di tengah pandemi COVID-19, dalam hal ini BK sangatlah penting dalam memberikan layanan kepada peserta didik. Hal ini bertujuan untuk mengetahui perkembangan kompetensi dan kemandirian peserta didik (Tambusai, 2020).

Dengan adanya proses pembelajaran menggunakan daring atau online sesuai dengan instruksi Menteri Pendidikan. Peserta didik melakukan pembelajaran di rumah dan mengembangkan life skill di masa pandemi secara online, dalam hal ini media layanan bimbingan konseling juga harus mampu memotivasi peserta didik untuk terus belajar di rumah. Fenomena ini menjadi tantangan dan tuntutan Bimbingan Konseling untuk mampu menerapkan berbagai bentuk media layanan dengan mengoptimalkan aplikasi, sedangkan dari peserta didik dituntut mampu beradaptasi dengan sistem daring yang baru bagi mereka (Musdalifah, 2021).

Usaha yang dilakukan layanan bimbingan dan konseling di sekolah untuk membantu peserta didik dalam pengembangan kehidupan pribadi, kehidupan sosial, kegiatan belajar, serta perencanaan dan pengembangan karir. Bimbingan dan Konseling memberikan pelayanan untuk memfasilitasi pengembangan peserta didik secara individual, kelompok, dan atau klasikal, sesuai dengan kebutuhan, potensi, bakat, minat, perkembangan, kondisi, serta peluang-peluang yang dimiliki (Purwaningsih, 2021)

Bimbingan merupakan bantuan yang diberikan kepada individu untuk mencapai pemahaman diri dan arah diri terutama untuk membuat penyesuaian maksimal terhadap sekolah, rumah tangga dan masyarakat umum (Djumhur \& Surya, 1995).

Bimbingan di sini berarti bahwa bimbingan merupakan sebuah bantuan khusus yang diberikan siswa yang bermasalah, agar mereka dapat mengerti kesulitannya, memahami permasalahannya serta mampu untuk mengatasi kesulitannya, sehingga dapat tercapai tujuan 
dari pendidikan yang sesuai dengan keadaan lingkungan sekolah, dan keluarga serta masyarakat. Dapat ditarik kesimpulan bahwa bimbingan adalah suatu bantuan atau pertolongan yang diberikan oleh seseorang yang memiliki kemampuan, kepada setiap individu untuk mengembangkan dirinya, dalam mencapai kebahagiaan

Konseling dapat diartikan sebuah bantuan yang diberikan kepada individu untuk memecahkan masalah kehidupannya dengan cara interview, cara ini merupakan cara yang sesuai dengan keadaan individu untuk mencapai kesejahteraan hidupnya melalui konseling individu akhirnya dapat memecahkan masalah dengan kemampuannya sendiri (Djumhur \& Surya, 1995).

Tujuan dari penulisan artikel ini untuk mengetahui bagaimana peran BK di sekolah, apakah pelaksanaan bimbingan dan konseling sudah berjalan sebagaimana mestinya atau masih banyak kekurangannya. Dengan demikian kita dapat mengetahui pelaksanaan bimbingan dan konseling secara nyata di suatu sekolah sehingga dapat dijadikan acuan atau bahan pertimbangan kita sebagai calon tenaga pendidik agar kedepannya dapat menerapkan serta melaksanakan suatu bimbingan kepada peserta didik dengan lebih baik lagi.

\section{Metode}

Sesuai fokus yang melatarbelakangi permasalahan juga tujuan penelitian, maka penelitian ini dirancang untuk memahami dan memaparkan peran guru BK dalam layanan bimbingan konseling pada siswa. Hal tersebut meliputi, tantangan atau hambatan, dan cara penanganan. Selain itu, juga dirancang untuk mengetahui tanggapan siswa mengenai layanan bimbingan konseling di sekolah.

Penelitian ini menggunakan metode mixed method design sequence. Metode ini dipilih dengan tujuan agar hasil yang didapatkan lebih akurat dan maksimal. Pendekatan kualitatif dirancang untuk mengetahui cara BK bekerja di sekolah. Sedangkan pendekatan kuantitatif digunakan untuk mengetahui berapa banyak siswa yang memanfaatkan layanan konseling dan ada tidaknya layanan bimbingan dan konseling yang ditawarkan oleh guru BK di masa pandemi.

Teknik pengumpulan data menggunakan metode wawancara mendalam, studi deskriptif, observasi, dokumentasi, dan menggunakan observasi tes tulis dengan pengisian lewat google form. Dalam penelitian ini peneliti bertemu dengan tiga Guru Bimbingan Konseling dari sekolah yang berbeda-beda, tetapi dalam jenjang penugasan yang sama. Ketiga sekolah tersebut yaitu, SMA Negeri 1 Godong yang terletak di Kabupaten Grobogan, SMA Negeri 1 Sragi yang terletak di Kabupaten Pekalongan, dan MA Al-Anwar yang terletak di Kabupaten Rembang. Dan dari tiga sekolah tersebut, diperoleh juga sembilan nama siswa yang bersedia mengisi kuesioner, yang masing-masing dari tiga siswa berasal dari sekolah yang sama. Hal ini dilakukan untuk mendapatkan perbandingan, agar data yang didapat lebih relevan. Penelitian ini dilakukan selama tiga hari berturut-turut. Dimual dari tanggal 30 September 2021 sampai 2 Oktober 2021. Dalam proses penelitian setelah data dikumpulkan, maka diperoleh tahap berikutnya yang paling penting adalah melakukan teknik analisis dengan model interaktif. Dengan menggunakan google form, analisis data statistik deskriptif dapat dilakukan dengan penyajian data berbentuk diagram dari sembilan responden yang ada. Selanjutnya, analisis data yang lain menggunakan reduksi data, untuk memilah sesuatu yang tidak perlu untuk mempermudah menarik kesimpulan. 


\section{Hasil dan Pembahasan}

\subsection{Hasil}

Wawancara yang ditujukan pada guru BK dilakukan secara langsung melalui tatap muka dan lewat Google Formulir, sedangkan proses observasi yang ditujukan pada siswa dilakukan dengan menggunakan website google form karena masih dalam pandemi COVID-19. Sasaran observasi ini adalah tiga sekolah, yaitu SMAN 1 Sragi Pekalongan, SMAN 1 Godong Grobogan , dan MA Al Anwar Rembang. Dengan memfokuskan pada layanan bimbingan dan konseling pada kelas XII di ketiga sekolah tersebut. Pemilihan kelas XII sebagai subjek penelitian utama karena kelas XII merupakan kelas yang pernah mengalami pembelajaran secara offline dan juga secara online sehingga dapat membandingkan antara pembelajaran secara offline dan online. Data yang didapatkan dari ketiga sekolah akan dibandingkan. Berikut ini adalah hasil observasi dari ketiga sekolah.

\subsubsection{Wawancara Terhadap Guru}

Penelitian yang dilakukan di tiga sekolah berbeda, yaitu SMAN 1 Sragi, SMAN 1 Godong, dan MA Al-Anwar dapat diketahui bahwa masing-masing guru tetap melakukan kegiatan bimbingan konseling di masa pandemi seperti saat ini. Mereka memiliki cara yang hampir sama dalam memberikan pelayanan bimbingan konseling kepada siswanya yaitu melalui konsultasi online menggunakan platform WhatsApp, dan dilanjutkan home visit jika layanan secara online dirasa masih kurang dalam menemukan solusi. Hal ini dapat diketahui dari jawaban yang diberikan oleh ketiga guru kepada peneliti.

"Jadi, Bimbingan dan Konseling tidak hanya dilakukan saat situasi normal. Kami memanfaatkan platform online seperti WA dalam menjalankan tugas. Tapi, di kondisi pandemi seperti ini justru lebih diperlukan karena secara normal anak mengikuti pembelajaran. Tetapi, saat kondisi seperti ini banyak anak yang tidak mengikuti PJJ (Pembelajaran Jarak Jauh) yang disebabkan karena banyak faktor: 1) sinyal, 2) kuota, 3) paling banyak ditemui adalah karena peserta didik yang bangun siang. Jadi, peran BK selalu memotivasi siswa," ujar Bu Ani (SMAN 1 Sragi).

"Konseling dilakukan melalui beberapa cara. Untuk konseling individual dilakukan melalui WA. Sedangkan untuk layanan bimbingan klasikal dilakukan melalui google classroom. Terkadang terdapat siswa yang melakukan konseling tatap muka secara terbatas dengan tetap mematuhi protokol kesehatan secara ketat," jelas Bu Suci (SMAN 1 Godong).

Sedangkan Ibu Siti Chotjah yang merupakan guru MA Al-Anwar mengatakan,

"Melakukan konseling seperti biasa untuk anak yang berada di pesantren Anwar 2, melakukan panggilan orang tua dan home visit jika memang diperlukan."

Masalah yang sering ditangani juga tak jauh berbeda, yaitu terkait rendahnya motivasi belajar siswa dan juga presensi kehadiran siswa yang dipicu adanya keterbatasan sinyal, kuota dan faktor lain. Dalam memberikan layanan, ada banyak hal yang menjadi hambatan juga tantangan tersendiri, apalagi di masa pandemi saat ini.

Ibu Ani yang merupakan Guru BK di SMAN 1 Sragi mengatakan,

"Kebanyakan tidak mengikuti PJJ (Pembelajaran Jarak Jauh) karena tidak belajar di sekolah anak tidurnya sering begadang atau sampai dini hari dan tidak terkontrol 
karena bangun sampai jam 11.00 WIB padahal pembelajaran dimulai dari jam 07.15

- 12.00 dari pihak orang tua mungkin sudah selalu menasehati anaknya sendiri.

Masalah lainnya seperti: sinyal dan kuota. Tetapi, hal ini masih bisa ditangani."

Narasumber kami yang kedua, yaitu Ibu Suci (SMAN 1 Godong) juga menerangkan bahwa yang menjadi permasalahan utama yang sering ditangani yaitu terkait rendahnya motivasi siswa.

Sedangkan Ibu Siti Chotjah yang merupakan guru MA Al-Anwar mengatakan,

"Kebanyak siswa tidak masuk tanpa alasan yang dilakukan berkali kali bahkan ada yang beberapa hari berturut turut."

Dalam memberikan layanan, ada banyak hal yang menjadi hambatan juga tantangan tersendiri, apalagi di masa pandemi saat ini. Secara umum, narasumber kami menjawab jika tantangan tersebut berasal dari siswanya sendiri selain keterbatasan media yang digunakan untuk layanan. Siswa cenderung malu untuk mengatakan masalahnya kepada guru BK, hal ini menjadi faktor utama tidak terentaskannya masalah secara cepat.

"Kalau normal, langsung bisa memanggil siswa. Tetapi, kalau di masa pandemi saat ini agak kesulitan paling dilakukan secara online dalam menghubungi siswa. Jika, siswa tidak mengikuti beberapa mata pelajaran karena ada informasi dari bapak/ibu guru bahwa anak tersebut tidak mengikuti. Nah, kami selaku guru BK hanya bisa menghubungi hanya bisa menghubungi anak tersebut melalui WA (jika nomer WA anaknya aktif) kalau tidak ada berarti kami harus melakukan tindak lanjut yaitu menghubungi orang tuanya. Tetapi, kendala disini anak tidak memberikan nomor orang tuanya di sekolah dan langkah selanjutnya kami melakukan home visit ke rumah anaknya. Tetapi, dalam hal ini kami selalu menerapkan prokes kesehatan. Agar siswa bisa kembali menjalani PJJ (Pembelajaran Jarak Jauh) dan melakukan kerja sama dengan orang tua agar selalu memotivasi anaknya agar lebih rajin mengikuti PJJ. Kendalanya sulit. Tetapi, kami tidak kehabisan akal." ujar Bu Ani (SMAN 1 Sragi).

"Hambatan yang ditemui selama masa pandemi yaitu ketika memberikan tugas kepada siswa melalui Google Classroom, masih banyak siswa yang belum mengumpulkan secara tepat waktu. Ketika melakukan konseling pribadi melalui WA, terkadang siswa kurang dapat memahami maksud yang ingin kita sampaikan, sehingga konseling menjadi kurang efektif," jelas Bu Suci (SMAN 1 Godong).

Sedangkan Ibu Siti Chotjah yang merupakan guru MA Al-Anwar mengatakan,

"Hambatan saat ini tidak mudah untuk melakukan panggilan orang tua dan home visit karena kendala pandemi jadi pihak BK hanya bisa menjangkau daerah yang dekat saja."

Selain itu, saat ini masih banyak siswa yang memiliki pola pikir bahwa siswa yang melakukan bimbingan konseling hanyalah siswa bermasalah. Untuk itu , masing-masing Guru BK terus mengupayakan dan memberi pemahaman kepada siswa untuk menghilangkan perspektif siswa bahwa hanya siswa yang bermasalah yang dapat melakukan bimbingan konseling, dengan begitu aka nada banyak siswa yang mau melakukan layanan bimbingan dan konseling. 


\subsubsection{Wawancara dengan Siswa}

Selain wawancara dengan guru BK, kami juga melakukan wawancara dengan siswasiswi di ketiga sekolah tersebut. Dalam satu sekolah, kami melakukan wawancara dengan tiga narasumber yang mewakili siswa di sekolah mereka. Hal ini bertujuan agar data yang kami peroleh lebih relevan. Dan dari hasil wawancara yang kami lakukan diketahui bahwa para siswa sudah mengetahui peran atau fungsi BK di sekolah secara umum. Kebanyakan dari mereka menjawab, peran BK di sekolah yaitu membantu memecahkan masalah yang dialami siswa.

Dalam masa pandemi seperti saat ini hanya beberapa siswa yang melakukan bimbingan dan konseling. Dari responden yang berjumlah sembilan siswa sebanyak 44,4 \%, responden mengatakan melakukan bimbingan konseling, dan 56,6\% nya tidak melakukan bimbingan konseling di masa pandemi ini (Gambar 1).

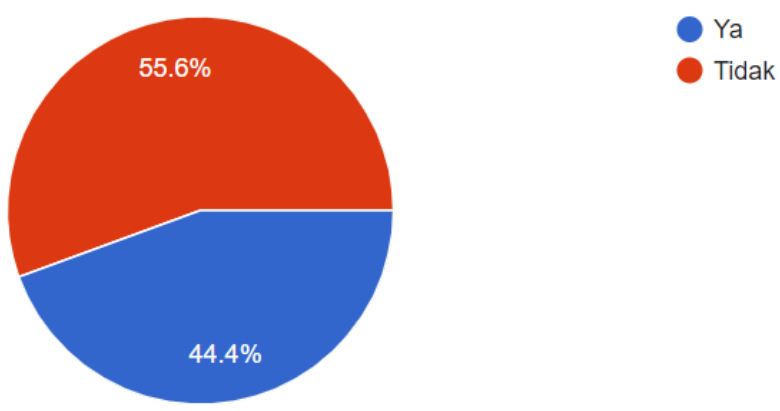

\section{Gambar 1. Diagram Perbandingan Kegiatan Bimbingan dan Konseling}

Sebanyak 55,6 \% persen mengatakan jika guru BK tetap memberikan penawaran terkait layanan bimbingan konseling di masa pandemi, sedangkan 33,3 \% mengatakan tidak ada penawaran, dan sisanya mengatakan mungkin (Gambar 2).

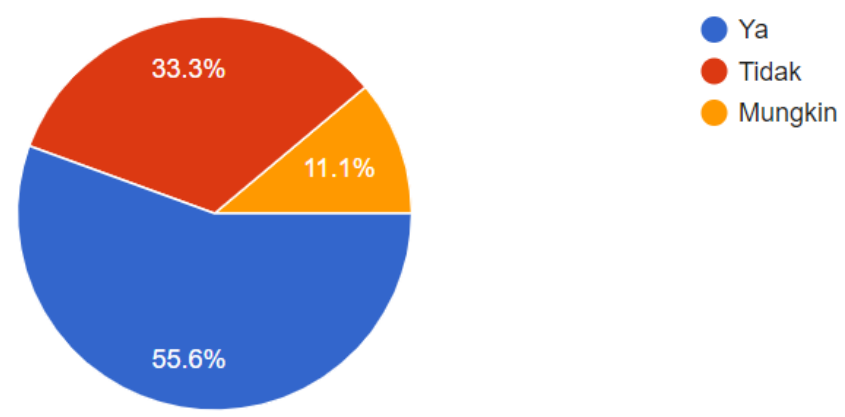

Gambar 2. Diagram Penawaran Layanan Bimbingan dan Konseling

\subsection{Pembahasan}

Bimbingan dan konseling berasal dari dua kata yaitu guidance dan counseling. Guidance menurut Winkel dan Hastuti (2007) berasal dari kata guide, yang berarti penunjuk jalan, pemimpin, penuntun, pemberi petunjuk, pengatur, pengarah, pemberi nasihat. Sedangkan 
menurut Yusuf dan Nurihsan (2012), guide berarti mengarahkan, memandu, mengelola, dan menyetir.

Layanan bimbingan dan konseling di sekolah dirancang untuk membantu siswa mengembangkan kehidupan pribadi, kehidupan sosial, kegiatan belajar, juga perencanaan dan pengembangan profesional. Penawaran bimbingan dan konseling mendorong perkembangan peserta didik secara individu, kelompok dan/atau klasikal sesuai dengan kebutuhan, potensi, bakat, minat, perkembangan, kondisi dan kemungkinannya. Layanan ini juga membantu mengatasi kelemahan dan kendala, serta permasalahan siswa (Kamaluddin, H. 2011).

Bimbingan dan Konseling di Indonesia secara resmi masuk dalam sistem pendidikan nasional mulai tahun 1975 ketika kurikulum 1975 diterapkan di sekolah menengah dasar di seluruh Indonesia. Artinya, profesi bimbingan dan konseling telah diakui di sekolah-sekolah. Profesi yang seharusnya membantu mendukung dan mengembangkan seluruh kemampuan siswa sesuai potensinya melalui layanan konseling dan konseling preventif dan kuratif (Astuti, R.W., dkk. 2013).

Maret 2020 Covid-19 mulai memasuki wilayah Indonesia. Hal ini berdampak pada seluruh sektor yang ada di Indonesia terutama sektor pendidikan. Hal ini memaksa pemerintah mengambil langkah cerdas, salah satunya yaitu menerapkan sistem pembelajaran online agar kegiatan pembelajaran tetap berlangsung. Karena terdapat aturan tersebut, maka semua aktivitas belajar mengajar dilakukan secara online atau daring. Hal ini juga berlaku untuk Bimbingan dan Konseling juga penerapan sistem layanannya.

Berkaitan dengan hal tersebut, menurut Nasution (2008), ada beberapa media pembelajaran online yang tersedia sebagai pilihan layanan bimbingan. Media online pertama dan terpopuler adalah Grup WhatsApp, Zoom, Media Online, lalu Google: Google Suite for Education, Media Online Ruang Guru, Media Online Zenius.

Layanan saran media lainnya juga dapat menggunakan google form untuk menyebarkan survei dan skala penilaian untuk mengetahui hasil pemahaman siswa. Aplikasi pendukung lainnya yang juga sangat berguna dalam proses advisory adalah aplikasi cyber advisory (Virtual World Advisory Service). Ini adalah layanan konsultasi profesional yang memungkinkan saran online pribadi, termasuk penasihat dan penasihat melalui media konferensi video. Layar komputer/smartphone merupakan kehadiran fisik kedua belah pihak dan dapat dilakukan kapan saja, dimana saja. Media yang digunakan antara lain website, blog, email, Facebook, Yahoo Messenger, Twitter, dan Instagram conference call/video conference (Skype, Video Call, Google Meet, Zoom, Hangouts) (Musdalifah, 2021).

Dari hasil wawancara yang dilakukan terhadap ketiga guru BK di sekolahan berbeda yang tersebar di Jawa Tengah, dapat diketahui bahwa masing-masing guru tetap melakukan kegiatan bimbingan konseling di masa pandemi seperti saat ini. Mereka memiliki cara yang hampir sama dalam memberikan pelayanan bimbingan konseling kepada siswanya yaitu melalui konsultasi online menggunakan platform WhatsApp, dan dilanjutkan home visit jika layanan secara online dirasa masih kurang dalam menemukan solusi. Masalah yang sering ditangani juga tak jauh berbeda, yaitu terkait rendahnya motivasi belajar siswa dan juga presensi kehadiran siswa yang dipicu adanya keterbatasan sinyal, kuota dan faktor lain. Dalam memberikan layanan, ada banyak hal yang menjadi hambatan juga tantangan tersendiri, apalagi di masa pandemi saat ini. Secara umum, narasumber kami menjawab jika tantangan 
tersebut berasal dari siswanya sendiri selain keterbatasan media yang digunakan untuk layanan. Siswa cenderung malu untuk mengatakan masalahnya kepada guru BK, hal ini menjadi faktor utama tidak terentaskannya masalah secara cepat. Selain itu, saat ini masih banyak siswa yang memiliki pola pikir bahwa siswa yang melakukan bimbingan konseling hanyalah siswa bermasalah. Untuk itu, masing-masing guru BK terus mengupayakan dan memberi pemahaman kepada siswa untuk menghilangkan perspektif siswa bahwa hanya siswa yang bermasalah yang dapat melakukan bimbingan konseling, dengan begitu akan nada banyak siswa yang mau melakukan layanan bimbingan dan konseling.

Dalam kegiatan layanan, ketiga Guru BK yang kami wawancarai bekerjasama dengan guru mata pelajaran juga masyarakat sekitar. Beberapa dari narasumber kami mengatakan jika ada beberapa masyarakat yang tidak mau diajak bekerja sama, dan narasumber yang lain mengatakan jika semua guru mata pelajaran juga masyarakat mau diajak bekerja sama dalam layanan bimbingan konseling. Namun meskipun begitu, para Guru BK tetap mengupayakan dan memberi pengarahan pada masyarakat sekitar agar ikut andil dalam penanganan masalah siswa di lingkungan mereka. Hal ini dapat menjadi alternatif lain bagi Guru BK untuk mengetahui masalah siswanya, jika siswa sulit diajak berkomunikasi atau malu.

Selain wawancara dengan Guru BK, kami juga melakukan wawancara dengan siswasiswi di ketiga sekolah tersebut. Dalam satu sekolah, kami melakukan wawancara dengan tiga narasumber yang mewakili siswa di sekolah mereka. Hal ini bertujuan agar data yang kami peroleh lebih relevan. Dan dari hasil wawancara yang kami lakukan diketahui bahwa para siswa sudah mengetahui peran atau fungsi BK di sekolah secara umum. Kebanyakan dari mereka menjawab, peran BK di sekolah yaitu membantu memecahkan masalah yang dialami siswa. Sebanyak 44,4 \%, narasumber mengatakan melakukan bimbingan konseling, dan 56,6\% nya tidak melakukan bimbingan konseling di masa pandemi ini. Sebanyak 55,6 \% persen mengatakan jika guru BK tetap memberikan penawaran terkait layanan bimbingan konseling di masa pandemi, sedangkan 33,3 \% mengatakan tidak ada penawaran, dan sisanya mengatakan mungkin. Hal ini bisa dikaitkan dengan jawaban Guru BK, yang mungkin saja siswa tersebut tidak mengetahui informasi layanan akibat terbatasnya media yang digunakan untuk penyampaian informasi. Namun, meskipun begitu mereka tetap mampu menjawab pertanyaan terkait tingkat keefektifan layanan bimbingan dan konseling secara online.

Dari hasil wawancara, dapat disimpulkan bahwa wawancara yang dilakukan secara online kurang efektif karena pewawancara tidak bisa melakukan timbal balik dari jawaban narasumber dan hasil jawaban narasumber juga kurang memuaskan, terutama siswa SMA yang jawabanya kurang tepat dari pertanyaan.

\section{Simpulan}

Berdasarkan dari temuan penelitian sebagaimana yang telah penulis uraikan pada babbab sebelumnya dapat ditarik kesimpulan bahwa dari hasil wawancara yang telah dilakukan terhadap ketiga guru BK di sekolahan yang berbeda yang tersebar di Jawa Tengah, dapat diketahui bahwa masing-masing guru tetap melakukan kegiatan bimbingan konseling di masa pandemi walaupun melalui konsultasi online dengan menggunakan platform Whatsapp, dan dengan media sosial lainya dan dilanjutkan dengan home visit jika layanan secara online dirasa masih kurang dalam menemukan solusi. Tetapi Masalah yang sering ditangani guru dalam bimbingan konseling juga tak jauh berbeda, yaitu kurangnya pemahaman siswa tentang penggunaan media untuk layanan sehingga mengakibatkan keterbatasan siswa dalam 
penggunaan media untuk layanan dan dengan terkait rendahnya motivasi belajar siswa yang belum paham tentang arti dari bimbingan konseling serta kurangnya pengetahuan tentang tujuan dan manfaat dari bimbingan dan konseling. Dan adapun faktor lainya yaitu siswa cenderung merasa malu dan kurang berani untuk mengatakan permasalahanya kepada guru BK, sehingga guru BK tidak tau permasalahan dari siswa dan hal ini yang menjadi faktor utama tidak terentaskannya masalah secara cepat. Selain itu, para siswa juga banyak yang memiliki pola pikir bahwa siswa yang melakukan bimbingan konseling hanyalah siswa yang bermasalah, dari pernyataan tersebut dapat disimpulkan bahwa banyak siswa belum memiliki pemahaman penuh mengenai bimbingan konseling. Guru BK dalam menjalankan bimbingan konseling juga bekerja sama dengan masyarakat sekitar untuk mengetahui problematika siswa, Hal ini dapat menjadi salah satu solusi bagi guru BK untuk mengetahui masalah siswanya lewat pendekatan melalui lingkungan sekitar, apabila siswa sulit diajak berkomunikasi dan malu untuk bercerita.

Hasil wawancara yang dilakukan dengan siswa dapat disimpulkan bahwa para siswa dapat mengetahui peran atau fungsi BK di sekolah secara umum. Namun, kebanyakan dari mereka memilih abai dan bodo amat terkait pentingnya layanan bimbingan konseling, dan tidak menggunakan kesempatan tersebut untuk menyelesaikan problem yang tengah mereka hadapi dan ada siswa diantara mereka yang tertutup dengan permasalahannya sehingga guru BK tidak bisa mengetahui permasalahan dari siswa tersebut. Tetapi Kebanyakan dari mereka paham terkait peran BK di sekolah yaitu membantu memecahkan masalah dan memberikan solusi dari permasalahan yang dialami oleh para siswa. Dari ketiga narasumber wawancara tersebut dapat diketahui Sebanyak 44,4\%, mengatakan melakukan bimbingan konseling, dan 56,6\% nya tidak melakukan bimbingan konseling di masa pandemi ini. Sebanyak 55,6 \% mengatakan jika guru BK tetap memberikan penawaran terkait layanan bimbingan konseling di masa pandemi, sedangkan 33,3 \% mengatakan tidak ada penawaran, dan sisanya mengatakan mungkin.

\section{Daftar Rujukan}

Purwaningsih, H. (2021). Peran Guru Bimbingan dan Konseling dalam Melayani Peserta Didik di Masa Pandemi Covid-19. Jurnal Inovasi Pendidikan dan Pengajaran, 1(1),36-40. Retrieved from https://www.jurnalp4i.com/index.php/educational/article/view/53

Tambusai, K. (2020). Peran Bimbingan Konseling di Sekolah di Tengah Covid-19. Jurnal Ikatan Bimbingan dan Konseling Islam, 2(2),175-187.

Musdalifah, A. (2021). Media Daring Layanan Bk di Masa Pandemi Covid-19. Jurnal Bimbingan dan Konseling, 6(1),109-113. Retrieved from http://jurnal.um-tapsel.ac.id/index.php/Ristekdik/article/view/2685

Djumhur, I., \& Moh, S. (1995). Bimbingan Konseling di Sekolah. Bandung : CV.Ilmu

Winkel \& Hastuti. (2006). Bimbingan dan Konseling di Institusi Pendidikan. edisi revisi. Yogyakarta: Media Abadi.

Yusuf, S. \& Nurihsan, J. (2012). Landasan Bimbingan dan Konseling. Cet. Ketujuh. Bandung: Remaja Rosdakarya.

Kamaluddin, H. (2011). Bimbingan dan Konseling. Jurnal Pendidikan dan kebudayaan, 17(4),447-454. Retrieved from https://doi.org/10.24832/jpnk.v17i4.40

Astuti, R. W., Mochammad, N., Titn, I. P., Wiryo, N. (2013). Pelaksanaan Bimbingan dan Konseling Untuk Mengubah Persepsi Negatif Siswa di Sekolah Menengah Atas di Kabupaten Lamongan. Jurnal BK Unesa, 3(1), 271-280. Retrieved from https://doi.org/10.24832/jpnk.v17i4.40

Nasution. (2008). Berbagai Pendekatan dalam Proses Belajar \& Mengajar. Cetakan kedua belas. Jakarta : Bumi Aksara. 